\title{
A Breakdown of Civil-Military Relations: The Soviet Coup of 1991
}

\author{
HEINRICH MATTHEE \\ Centre for Military Studies, University of Stellenbosch
}

\section{INTRODUCTION}

In August 1991 a Committee for State Emergencies, consisting of the minister of defence and the chief of the KGB, ousted Mikhail Gorbachev from power in the Soviet Union. The coup was important for several reasons. The platoons of tanks that moved in Moscow's streets ended a long tradition of obedience by the Soviet military to the civilian Communist Party. In addition, the military coup also marked a decisive shift in the foundation of civilian control in the Soviet Union.

By analysing Soviet civil-military relations before the coup, this essay tries to determine how the military became involved in the coup. The essay then seeks to determine whether different theoretical frameworks, mostly based on American experience, could explain the breakdown of civil-military relations in the Soviet Union.

\section{SOVIET CIVIL-MILITARY RELATIONS FROM LENIN TO KHRUSCHEV}

The first Soviet government came to power in what was essentially an urban strike against the Tsarist state. There were tense civil-military relations at first, not because of the nature of military professionalism, but because of no unquestioned political loyalty among the amalgamated military at the outset.1)

The first Soviet governments addressed the potential conflict with the military by neutralizing political opposition and by bringing pressure to bear on the military to internalize the Communist Party's value system. During this period a system of control through surveillance, ideological controls and a dual structure of authority predominated. Control was exercised through the Main Political Administration(MPA) and military informer networks of the political intelligence organization.2)

After the Second World War the civilian leadership concluded that the military was supportive of the government under most conditions and political pressure on the military receded. Albright links this tendency to the late Stalin era.3) However, the action of Soviet leader Nikita Khrushchev against the defence minister, Marshal Georgi Zhukov, in the late fifties, after the latter weakened the MPA's influence in the military, suggests a later date. 
After Khrushchev the military lobbied actively for greater autonomy and for insulation from haphazard political interference. The era of Leonid Brezhnev saw the partypolitical apparatus in the military largely identifying with the military and turning its attention to helping military officers carry out their basic mission.4)

\section{THE BREZHNEV ERA}

Under Brezhnev the military was given a high degree of autonomy regarding most military matters, even as prime formulators of policy options for political leaders on issues with military dimensions.5) During the Brezhnev era there was also a great convergence of civilian and military leaders' values, emphasizing the unity of the Soviet state, a strong defense against external threats, superpower status and internal order.

The civilian and military leaders shared many values and had a similar social and political background, strengthened by organized socialization and politicization in the communist state. While less than ten percent of civilians were party members, more than seventy percent of officers were party members during the Brezhnev era.6)

In fact, the complex network of roles in which important military men were simultaneously senior party officials complicates the application of the concepts "civilian" and "military" here. Military reservations with some civilian policies were often shared with important segments of the party machine. The civilian party gave priority to developing military capabilities primarily because such capability advanced the party's own goals, including self-preservation.7)

The civilian party leaders and the military therefore made the system work by being responsive to each other. In the Soviet Union the only interests with power were those represented in the Communist Party and bureaucracies, and policy was made in a bureaucratic competition. In the absence of many civilian security experts, the military had a virtual monopoly on expertise, information and option formation.8)

The military's near-monopoly meant that the military also influenced the defence policy agenda. Military leaders tried to design military strategy to protect the essential core missions of their institutions, even when those institutional interests conflicted with defence policy as established by civilian leaders. Since civilian decisions were mostly made after compromises and concessions, the military frequently succeeded in defying the exact requirements of civilian policy.

The prerequisites for a civilian ability to force policy integration were a bureaucratic coalition in favour of the policy change and an effective policy handle. A policy handle is a way to redefine the nature of a policy decision and force change on a subordinate organization by removing the policy decision from the organization's exclusive area of expertise.9)

Where the party leadership, for whatever reason, chose to focus on an issue like nuclear arms policy, it could force change. The military autonomy was not so strong that the 
civilian party was isolated completely from matters of strategy.

At the same time, the more autonomous top military leadership benefited materially from the relatively high priority accorded the military in society. The military could also build up substantial forces. In so far as the military was involved in politics, it was predominantly involved in bureaucratic politics.

However, the military influence remained within the established one party-dominated framework. There was a deep-seated consensus in the civilian party organs after Stalin against any pronounced upgrading of military influence. The military's influence remained limited, also in the short period between Brezhnev and Gorbachev. 10)

\section{THE WEAKENING OF MILITARY AUTONOMY UNDER GORBACHEV}

General secretaries of the Communist Party have played a critical role in deciding how permeable the borders of military autonomy have been. Mikhail Gorbachev was no exception and his policy of restructuring or perestroika considerably changed civil-military relations in the Soviet Union.

When Gorbachev came to power his aim was clearly economic revitalization. One of several constraining forces was the defense agenda. The problem was less the resources that were already going to the military, than the future resource commitments implied by threat assessments and requirements derived from traditional security thinking. Gaining control of the defense agenda was a necessity for Gorbachev's policy success.11)

Previously secrecy and a near-monopoly on military expertise had locked other institutional actors out of the defence policy process. However, Gorbachev turned for new ideas to non-military professionals in academia, party staff and the ministry of foreign affairs. These new actors found themselves in a competition among themselves and with the military bureaucracy to influence policy.12)

Non-military influences on policy regarding conventional force planning cut to the heart of military autonomy and professionalism, and the unilateral Soviet force and budget reductions which followed therefore inflamed the military's institutional ire. A hardening of professional attitudes among military leaders against military reforms were noticed months before the coup.13)

\section{THE FRAGMENTATION AND POLITICIZATION OF THE MILITARY}

As defence allocations were being cut, the military leadership was especially worried about saving high-priced weapons programs.14) However, the poor living and working conditions of the junior officer corps received little attention. Tens of thousands of officers and their families were without minimal housing, but the junior officers remained unsuccessful in getting the issue on the military agenda. This situation created potential lines of fragmentation in the Soviet military.15) 
The professional and generational divisions in the military were reinforced by public criticism of the military and internal political polarization. During the late 1980 s there were strong anti-military currents in Soviet society, dating back to the Afghan war experience and society's rejection of the war's veterans. Media sensationalism about the expensiveness of military power in the economically-stricken Union and military maltreatment of conscripts led to severe public criticism of the military.16)

The military, attacked from many sides, was motivated to publicly speak out on issues of professional concern and in institutional defence. The military was drawn into public debates on more and more issues. No steps were taken to prevent officers from expressing their personal political opinions in the press or from becoming members of political organizations.

To the senior military the Communist Party remained a solid supporter, while other political forces were attacking the institutional interests of the military. The declining civilian interest in the Communist Party also offered new opportunities for senior officers' activism and influence within the party.

In contrast, the junior officers saw that party membership, previously a requisite for a top career, would not be career-enhancing any more, but that membership of other reformist or nationalist movements may be career-enhancing in the politicized environment. Lowerranking officers could outflank the military chain of command and establish an independent power base from which to press their professional and political agendas.17)

\section{THE DECLINE IN CIVILIAN AUTHORITY AND LEGITIMACY}

The fragmentation and politicization of the military occurred in a society where the authority of the Communist Party was declining. Gorbachev's attempts to replace the one party-dominated political system with one based on democratically-elected legislatures did not effectively transfer power to a presidential central authority.

The bureaucratic system holding together regions of diverse resources, cultures, clans and religions, was weakened. This power vacuum allowed republican leaders to demand a greater role in policy-making. Some republics started to pass laws to void union laws. A contest of power erupted which undermined the center's perceived competence, authority and power.18)

The rise of political institutions at many levels of government provided opportunities for overt political activism by military officers in the nascent domestic political process, including direct interaction with civilian politicians. The contest of power between the central authority and the republics, and domestic military missions to establish order, also amplified the politicizing impact of nationalist movements on the conscript pool.19) 
The decay of other major institutions of the central authority, like the Communist Party apparatus, left the military as one of the weakened but comparatively strong central

institutions. Consequently, as part of their contest with the central authority, many republics tried to restrict the central Soviet military by new laws.

\section{THE CHALLENGE TO CORE MILITARY VALUES AND INTERESTS}

The long-term threat of republican challenges to the center constituted a great threat to the centrally controlled Soviet military. Some republics started preparations to suspend central conscription and the deployment of republican nationals by the central military. Local support to central military installations was cut off and several military bases closed down by republican governments.20)

The republican assertiveness presented an organized political threat to the military's institutional prerogatives. The military leadership was discontent with the way the civilian party leadership was reacting to the escalating challenges to central authority and the Soviet military institution. Gorbachev's planned Union Treaty of 20 August would acknowledge power-sharing with the republics, and was seen as a further step in a process threatening the Soviet military institution.

Apart from such discontent, there was also officer discontent against the senior military command, which had proved itself incapable of addressing the concerns of the junior officer corps. The senior military therefore presided over a moderately pro-centralist but divided officer corps and a republican-orientated conscript army. The divided officer corps could not be mobilized on the national level and could not act as a coherent political force.21)

At the same time that several interests in the KGB, the military, the defence industry and the central bureaucracy were threatened, Gorbachev himself had an increasingly weak power base in the party. Opposition to Gorbachev's leadership crystallized during the socalled "constitutional coup" of June 1991, when prime minister Pavlov attempted to usurp many of Gorbachev's presidential powers. The attempt had the support of the minister of defence, Yazov and the head of the KGB, Kruychov. Gorbachev defeated the attempt, but did not act against the dissident group.22)

By August 1991 the heads of the increasingly powerful republics, including the elected leader of the Russian republic, Boris Yeltsin, wanted the removal of the minister of defence and the head of the KGB. At the same time, the military senior command faced the possible removal of Communist Party structures from the military and the KGB in the Russian republic. There was also a $50 \%$ decline in new orders to the defence industries and the possibility of another reformist split in the Communist Party.23) 


\section{THE OPAQUE ROLE OF GORBACHEV}

Instead of trying to consolidate the Communist Party or to broaden his tenuous support for the Union treaty before the planned signing on 20 August 1991, Gorbachev and his family took a fortnight's holiday. The holiday started on 4 August and was far away from the power center. This behaviour was out of keeping and could also suggest that Gorbachev was leaving the field expressly to others.24)

Gorbachev has claimed that he was without communications during the coup and blockaded at his house. There are several contrary indications, however. The coup organizers were Gorbachev's men. He opened the way for Kryuchkov in the KGB, for Pavlov as prime minister, for Pugo as minister of the interior, for Yanayev as vice-president and for Yazov as minister of defence. They were all part of Gorbachev's immediate circle and of the eight man State Committee for State Emergencies which organized the coup.25)

On 18 August some of them went to see him in the Crimea, to gain his permission for a state of emergency. When the coup started to unravel on 21 August, they again tried to gain his support for such a measure. During Gorbachev's flight back to Moscow, he at first did not want to arrest Kryuchkov and defended the army chief of staff and coup supporter Moiseev. Gorbachev's conduct suggests that he either had an agreement with the coup organizers or thought that he could control them again through manipulation

The coup organizers included competent professionals like Kryuchkov and Yazov, and yet the coup was not well orchestrated. The coup organizers said afterwards that they were convinced that they could persuade Gorbachev to remain incommunicado while they tried to implement a state of emergency. Gorbachev's account of the conversations with the plotters supports their account.26)

As Pryce-Jones and others have stated, Gorbachev's style was often oblique, a matter of nods and hints".27) The coup plotters already had all the power they could possibly want in the key positions. The possibility cannot be excluded that, as Yeltsin initially thought and as the plotters allege, Gorbachev in his projections of a state of emergency hinted that he was aware of the plotters' plans for a state of emergency and that he would back success but disavow failure.

Gorbachev would have benefited from a centralist crackdown on the national republican forces without having to sully his international reputation. After a successful stabilization led by security bureaucrats he would probably have been able to enter politics again. On the other hand, his conduct could be explained by a risky strategy to manipulate his assembled centralist team to ward off democratic and republican forces while implementing reformed communism.28) 


\section{THE COUP OF AUGUST 1991}

However, Gorbachev's main team, driven by the KGB leader Kryuchov, was not completely under his control. On 19 August 1991, the State Committee for State Emergencies, hereafter referred to as the Committee, announced a state of emergency in Gorbachev's absence. Military forces were deployed in Moscow and elsewhere and Gorbachev was visited by a delegation of the coup organizers.

Gorbachev refused to agree to a state of emergency to stop the disintegration of the Soviet Union. However, he did not detain the Committee delegation, although he had armed guards at his disposal. In his memoirs Gorbachev says that he expected the coup participants to come to their senses after his refusal, and that it was not the first time that he had restrained them from rash action.29)

The coup enjoyed the support of the majority in the Secretariat of the Communist Party's Central Committee, which was Gorbachev's power base. Polls conducted eventually showed that about 40 percent of the population sympathised with the coup and 70 percent of the regional party leadership.30)

However, most of the population remained passive during the coup. Under Gorbachev's rule, there had emerged civil society leaders but only the business community, who stood to lose if reforms were dismantled: so they quickly denounced the coup.31) The coup organizers wanted to shock Moscow's population into submission with an enormous display of faceless decrees, military hardware and ordinary soldiers.

However, there was no rapid neutralization of potential opposition leaders like Yeltsin. He went to the White House building in Moscow to defy the authority of the centralist Committee with his authority as elected leader of the Russian republic. Communication media remained available to him to mobilize support, also internationally. A big crowd of supporters, including many Russian youths and some Afghan war veterans, eventually assembled around the building, forming a human shield.

The coup organizers wanted to maintain good foreign relations and therefore wanted to avoid bloodshed. When Yeltsin, as elected Russian leader, succeeded in establishing a counter-pole of legitimacy, his arrest could provoke a sharp backlash of resistance, possibly leading to excessive force and bloodshed. Kryuchkov, according to some analysts, wanted to avoid such a possibility. Other analysts maintain that Kryuchkov continued to manoeuver hopes of capturing Yeltsin.32)

The middle-aged coup plotters may have underestimated the extent of the communication media in the information age. Instead of a quiet and inconspicuous coup in the corridors of power, they suddenly had a totally public issue in the full glare of publicity. The Committee did not have any internal or external leader, or an experienced media spokesperson. Not unexpectedly, the media appearances of the Committee members did not strengthen the public's perceptions about the Committee's legitimacy.33) 


\section{THE SOVIET MILITARY AND THE COUP}

When the Committee ousted Gorbachev and announced a state of emergency, virtually all of the top commanders, in spite of reservations, complied with the Committee's orders. While military commanders at all levels were willing to deploy forces, most balked when it came to employing the forces against those resisting the coup. Yeltsin and most of his supporters were ethnic Russians, like most Soviet military officers and 80 percent of the Soviet army.34)

The senior military command had three choices, to resist the strike against the state, to participate in the coup, or to stand aloof. The senior command could resist the coup, but it shared the concerns of the Committee. The senior command and the Committee agreed about the need to reassert central authority, to reign in republican governments, to re-establish law and order in society, and to bolster the declining prestige and influence of the military.

Alternatively, the senior command could support the Committee. However, to employ forces against those resisting the coup, risked igniting volatile political forces among the ranks. The senior command perceived a real potential for the complete disintegration of the Soviet military in such a case.35) As it turned out, the potential for intra-military clashes between units which repositioned themselves, did develop.

If the senior command did not want to actively resist or support the Committee, it could have chosen to stand aloof and allow the effort to re-establish central authority to fail. The risk of such a course of action involved the prospects that the Union could unravel haphazardly, resulting in the collapse of the central military establishment.

Eventually, the senior command fractured into three groups, with the majority standing aloof. There was no clear mission, no obvious enemy and no charismatic leadership for the military supporters of the coup. In addition, the coup's supporters were mixed in units with coup opponents, which immobilized the military.

The MPA and the KGB were more willing to support the coup than the regular military, but lacked the ability to push military commanders into action.36) However, the coup was probably doomed by the reluctance of the Russian centralist senior command members to employ forces against those resisting the coup, including Russian civilians assembled outside Yeltsin's White House. When the order was at last given to special troops to storm the White House, the unit to which the mission was assigned refused to obey.37)

There was no clear source of civilian control over the politicized and divided military during the coup. When elected Russian president Yeltsin declared that he was assuming control of security forces in Russia, this provided a strong alternative base of civilian authority in the capital and strongest republic of the Soviet Union.

During the contest over legitimacy the coup Committee failed to persuade the public that it was a legitimate authority. After three days, the coup Committee agreed to withdraw 
troops and Gorbachev was re-instated. However, Gorbachev never fully recovered his authority. The strike against the state, conducted to save the centralist Soviet Union, probably hastened the demise of the Soviet Union at the end of 1991.

\section{THE SEPARATION APPROACH IN THE SOVIET CONTEXT}

The breakdown in late Soviet civil-military relations and the coup can also be assessed with reference to existing perspectives on civil-military relations. One approach, followed by Samuel Huntington, stresses the separation between the military and civilian institutions.38)

Good civil-military relations, in Huntington's view, require a separation of civilian and military spheres, with civilians determining policy and the military implementing it. The separation approach is, however, based on American experience. While this approach implies a conflict between liberal democratic civilian authorities and the military, because of the conservative realist values in military professionalism, Soviet civil-military relations initially were not tense because of the nature of military professionalism.

Soviet civil-military relations were tense initially because the Communist Party rulers could not depend on the political loyalty of the diverse amalgamated military. A system was introduced in which the power of one civilian group, the Communist Party, was maximised in relation to the military and other civilian groups, by penetrating the military with civilian political values and interests. The means of penetration included the division of the officer corps into competing groups, ideological controls by the MPA and a dual structure of authority.39)

Samuel Huntington described this system as one of subjective control. Roman Kolkowicz argues that the Soviet system remained a dominantly subjective one. In contrast, Timothy Colton argues that the Soviet military was eventually under so-called objective control, with substantial autonomy from the civilian authorities and controlled by a selfrestraining professionalism from involvement in partisan politics.40)

The subjective model implies that civilians will seek to enlist the military in a winning coalition during periods of succession, with a resulting growth in military influence. However, during the succession period of Mikhail Gorbachev the military had a weak influence only. This seems to indicate that subjective civilian control was not dominant during the late Soviet Union.

The Brezhnev era's predominant control through a self-restraining military professionalism was allowed because of the effectiveness of previous subjective control. The military's interests and values were compatible with those of the civilian party and there was little threat of military involvement in partisan politics.41)

Soviet civil-military relations therefore were along a continuum of both conflict and cooperation during the Brezhnev era, but mostly cooperative. This situation contrasts with 
Huntington's approach, based on a multi-party democracy, that civil-military relations are inherently conflictual. In addition, while Huntington stressed that civilian authority and the military constitute two distinct groups, the Soviet example indicates an overlap in roles and personnel, also in the defence industry.

While the late Soviet system mostly did not involve a subjective control of the military, there was at most an incomplete objective control of the military in the late Soviet Union. The tasks of the MPA still included some elements of subjective control.42) After Gorbachev's reforms, several civilian groups, including the Communist Party, reformist groups and nationalist movements, also started to compete for influence in the military.

The centralist military's objective control depended on a self-restraining professionalism, and such professionalism depended on the military viewing itself as serving Soviet society. When the political developments and debates in society increasingly put the existence of such a society in question, the basis of Soviet military professionalism started to weaken.

The weakening of a self-restraining military professionalism did coincide with the military intervention in partisan politics, as Huntington's approach would suggest. However, the military intervention was not organized against the remaining institutions of subjective civilian control. In the Soviet case the coup was driven by the KGB and supported by the MPA, both institutions supposed to ensure civilian control.

Also, it can be argued that the predominantly self-restraining and autonomous military of the Brezhnev era served to desensitize the men who formed the leadership of the late Soviet military. The senior military command, committed to the professional defence of a centralist Soviet Union, may have misjudged the political currents and the discourses of different nationalisms and democracy.43)

The separation of the military and a self-restraining military professionalism may therefore have contributed to military intervention, rather than preventing such intervention. While Huntington's approach provides some analytical tools, it does not necessarily explain the breakdown in Soviet civil-military relations.

\section{THE INTEGRATION APPROACH IN THE SOVIET CONTEXT}

Huntington's approach emphasizes the separation of the military and civilian institutions as a means to stable civil-military relations. In contrast, a second theoretical approach stresses the close link between the military and society, and indicates that the military can never be completely separate from society.

According to this approach, followed by Morris Janowitz, the military will reflect society in important ways and social currents will find their way into the military at some stage.44) For stable civil-military relations, similar social backgrounds for civilian 
institutions and the military, as well as a meaningful integration between civilian and military values are suggested.

The occasionally unstable civil-military relations during the initial years of the Soviet Union, as well as the stable relations during the Brezhnev era, can be explained by this approach. The intense debates during the Gorbachev era in Soviet society on the role of the military indicated some conflict between civilian and military values, regarding the military budget, domestic involvement, training and the Afghan war.45)

The criticism of the military by different civilian actors and Gorbacnev's weakening of military autonomy and influence did cause tense civil-military relations. On the other hand, it can also be argued that the contest of values in society was merely reflected in the divided military too, so that the coup was not the result of a lack of integration between civilian and military values as such. However, the coup organizers shared the social backgrounds and values of the dominant centralist faction in the ruling civilian Communist Party.

Not only the strongest party faction, but also Gorbachev aimed at the retention of the Soviet Union. The Soviet coup leadership was also predominantly Russian, and the strongest civilian opposition to the deployment of the military forces was predominantly Russian. These similarities may have affected the willingness to use certain means during the coup, but they did not ensure stable civil-military relations.

The coup therefore was not the result of a lack of integration between civilian and military values as such. The contest of values and interests in Soviet society was in fact reflected in the divided military too. The integration approach therefore does not explain the breakdown in Soviet civil-military relations.

\section{THE CONCORDANCE APPROACH IN THE SOVIET CONTEXT}

Apart from the separation and integration approaches, Rebecca Schiff also tries to explain civil-military relations according to a so-called concordance or agreement approach.46) She sees separation or integration of civilians and the military as one of several possibilities for stable civil-military relations.

For Schiff, the specific kind of civil-military relationship is less important to deter military intervention in partisan politics than the degree of agreement between the political elites, the military and the citizenry. Schiff mentions four areas where agreement is necessary: the social composition of the officer corps, the political decision-making process, the method for recruiting the rank and file of the military, and also military style.47)

Applying the concordance approach in the case of the Soviet Union under Brezhnev may be difficult. In the absence of free multi-party elections, it is difficult to determine what the true values and the degree of consent of the civilian population were. Some analysts argue that eventually a subjective acceptance of Soviet identity went alongside a sense of 
specific national consciousness.48) At the same time, coercion and propaganda played an important role in establishing and maintaining the Soviet Union.

The centralist Soviet Union had to accommodate hundreds of nationalities in the different member republics. The political accommodation of nationalities, exploited also by local elites trying to get access or to maintain access to resources, fuelled disagreement among the citizenry, military and civilian leaders during Gorbachev's rule.49)

The contest between the center and the republics, the challenge to military values and interests, and social criticism of the military institution were directly related to the composition of the officer corps, the pattern of military recruitment, military style and the political decision-making process. Disagreement on the four areas mentioned by Schiff was therefore present during the breakdown in Soviet civil-military relations. The concordance approach does provide a plausible explanation for the collapse of Soviet civil-military relations.

\section{CONCLUSION}

The Communist Party was the main source of civilian control of the Soviet military. Strong measures to ensure control through specific political values in the amalgamated military characterized initial civil-military relations. As the civilian Communist Party and military elites came to share values, social backgrounds and interests, greater military autonomy and self-control characterized civil-military relations. However, the Gorbachev era again saw greater tension in civil-military relations.

Gorbachev's reforms were followed by less military autonomy, the growing fragmentation and politicization of the military, a decline in the influence of the central civilian authority and threats to core military values and interests. An alliance of threatened individuals and interest groups, also from the military and the Communist party, launched a coup d'etat under KGB command.

The coup organizers aimed to re-establish the authority of the Communist Party in a centralist Soviet Union. Gorbachev's conduct suggests that he either was willing to allow the coup organizers, his close associates, to proceed in case they could weaken his opponents at no cost to himself, or that he miscalculated his ability to control the centralist forces in his government. However, the main opponent of the coup organizers turned out to be Boris Yeltsin.

The coup organizers could not win enough influence to counter the influence of Boris Yeltsin in the most important Soviet republic, Russia. Yeltsin used his status as an elected republican president to establish successfully an alternative source of civilian control for the Russian military, and the coup organizers stopped their attempt after three days.

The breakdown in Soviet civil-military relations cannot be explained by the decline of military autonomy or civilian control alone. In fact, the military leadership's separation from 
broader society may have contributed to the coup, and the instruments of subjective civilian control drove the coup.

Similarly, the coup was not the result of the lack of integration between civilian and military values and backgrounds. Civilians and soldiers were on both sides of a coup that reflected the contest of values in the broader society of the Soviet Union.

Citizens in the military, civilian authorities and society as such seriously disagreed about the political decision-making process and the role and nature of the military. The concordance approach therefore provides an explanation for the breakdown in Soviet civilmilitary relations in 1991 . 


\section{REFERENCES}

1) Albright, D., "A Comparative Conceptualization of Civil-Military Relations", World Politics, Vol.32 No.4 July 1980, pp.553-576 on p.562.

2) Galeotti, M., The Age of Anxiety: Security and Politics in Soviet and post-Soviet Russia, Longman, Harlow 1995, pp.35-36.

3) Albright, op.cit., p..566. See however Du Plessis, L., Die politisering van die Sowjetsoldaat voor en tydens militêre diens, D. Phil. Thesis, University of Pretoria, Pretoria 1987, pp.211-212.

4) Rice, C., "The party, the military, and decision authority in the Soviet Union", World Politics, Vol.40 No.1 October 1987, pp.55-81, on p.60. See also Albright, op. cit. p.565 and Galeotti, op. cit., p.36.

5) Albright, D., "Democratization and Civil-Military Relations in Russia and Ukraine", in Lovell, J.P. and Albright, D.E. (eds.): To Sheathe the Sword: Civil-Military Relations in the Quest for Democracy, Greenwood Press, London 1997, pp.33-52 on p.36.

6) Du Plessis, op. cit., p.303.

7) Colton, T., Commissars, Commanders and Civilian Authority: The Structure of Soviet Military Politics, Harvard University Press, London 1979, p.280. See also Rice, op. cit., p.77.

8) Rice, op. cit., p.66

9) Kaufman, S., "Organizational Politics and Change in Soviet Military Policy", World Politics, Vol.46 No.3 April 1994, pp.355-382 on pp.362-363.

10) Colton, T., The Dilemma of Reform in the Soviet Union, Council on Foreign Relations, New York 1986, p.99.

11) Meyer, S., "The Sources and Prospects of Gorbachev's New Political Thinking on Security", International Security, Vol.13 No.2 Fall 1988, pp.124-163 on pp.128-129.

12) Leppingwell, J., "Soviet civil-military relations and the August coup", World Politics, Vol.44 No.2 July 1992, pp.539-572 on pp.550-551.

13) Mackintosh, M., The New Russian Revolution: The military dimension, Conflict Studies 247, RISCT, London 1992, p.3. See also Meyer, op. cit., p.155, Foreign

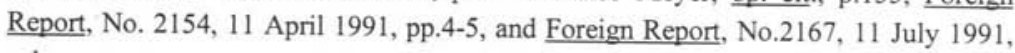
p.1. 
Scientia Militaria, South African Journal of Military Studies, Vol 29, 1999. http://scientiamilitaria.journals.ac.za

14) Occasionally there was a difference between the interests and objectives of the defence industries and the military. See Galeotti, op. cit., pp.117-118.

15) Meyer, S., "How the Threat (and the Coup) Collapsed: The Politicization of the Soviet Military", International Security, Vol.16 No.3 Winter 1991/1992, pp.5-38 on p.19.

16) Blacker, C., Hostage to Revolution: Gorbachev and Soviet Security Policy 1985-1991, Council on Foreign Relations, New York 1993, pp.164-166. See also Goldman, M., What Went Wrong with Perestroika?, W.W. Norton, London 1992, pp.198-199.

17) Meyer, op.cit, pp.15-16.

18) Ibid., pp.23-25.

19) Ibid., p.21. See also Taylor, B., "Russian Civil-Military Relations After the October Uprising", Survival, Vol.36 No.1 Spring 1994, pp.3-29 on p.6, and Holloway, D., "State, Society, and the Military under Gorbachev", International Security, Vol.14 No.3 Winter 1989/1990, pp.5-24 on pp. 18-20.

20) Goldman, op.cit., pp.198-199, and Meyer, op.cit., pp.23-25, 29.

21) Leppingwell, op.cit, p.559.

22) Ibid., p.562. See also Crawshaw, S, Goodbye to the USSR: The Collapse of Soviet Power, Bloomsbury, London 1992, pp.178-179.

23) Dunlop, J., The Rise of Russia and the Fall of the Soviet Empire, Princeton University Press, Princeton 1993, pp.194-196.

24) Pryce-Jones, D., The war that never was: The fall of the Soviet empire 1985-1991, Weidenfeld and Nicholson, London 1995, p.408-410. John Dunlop refers to the fact that many Western analysts have tended to accept Gorbachev's version of events, while analysts from the former Soviet Union have been less convinced. See Dunlop, op.cit., p.203.

25) Crawshaw, op.cit., p.187. See also Pryce-Jones, op. cit., pp.408, 424, and Dunlop, op.cit., pp. 203-206.

26) D'Agostino, A., Gorbachev's Revolution 1985-1991, Macmillan Press, London 1998, p.324. See also Gorbachev, M., Memoirs, Doubleday, London 1996, pp.631-632.

27) Pryce-Jones, op.cit., p.409. See also Dunlop, op.cit., p.206. 
28) Pryce-Jones, op.cit., p.413. See also Yeltsin, B. (translator Fitzpatrick, C.): The Struggle for Russia, Times Books, New York 1994, pp.65-66, and Dunlop, op.cit., pp.204, 257-260. For an opposing view, see Brown, A., The Gorbachev Factor, Oxford University Press, New York 1996, p.388.

29) Gorbachev, op.cit., p.632.

30) Ibid., pp.640-642. See also Dunlop, op.cit., pp.199-202, 236.

31) Yeltsin, op.cit., p.74. See also Dunlop, op.cit., pp.224-226.

32) Yeltsin, op.cit., pp.60,67. See also Dunlop, op. cit., p.246 and Shevtsova, L., "The August coup and the Soviet collapse", Survival, Vol.34 No.1 Spring 1992, pp.5-18, on p.7.

33) Yeltsin, op.cit., pp.57-58. See also Leppingwell, op.cit., p.563.

34) Donelly, C., "Evolutionary problems in the former Soviet armed forces", Survival, Vol.34 No.3 Autumn 1992, pp.28-42 on p.33. See also Shevtsova, op.cit, p.7, Gorbachev, op.cit., p.582 and Dunlop, op.cit., pp.249-250.

35) Meyer, op.cit., p.30.

36) For the role of the MPA, see Leppingwell, op.cit, p.564. For the role of the KGB, see Dunlop, op.cit, pp.207-210,250, D'Agostino, op.cit., p.320, and Adelman, J., Torrents of Spring: Soviet and post-Soviet politics, McGraw-Hill, New York 1995, p.231.

37) Dunlop, op.cit., pp. 242-247.

38) Huntington, S., The Soldier and the State: The Theory and Politics of Civil-Military Relations, Harvard University Press, Cambridge 1957, p.15-16, 80-85.

39) Albright, op.cit., pp.561, 565 .

40) Leppingwell, op.cit., pp.541-542.

41) Albright in Lovell and Albright, op.cit, pp.35-36. See also Leppingwell, op.cit., p.549 and Holloway, op.cit, pp.5-6.

42) Leppingwell, op.cit, pp.545-547.

43) Meyer, op.cit., pp.15,18 and 23. See also Leppingwell, op.cit.,p.553. 
44) See Janowitz, M., The Professional Soldier: A Social and Political Portrait, Free Press, New York 1971, p.420.

45) Ironically, Afghan war veterans would play an important role in the defiance of the military forces deployed by the coup organizers around the White House. See Dunlop, op.cit., pp.222-223.

46) Schiff, R., "The Indian Military and Nation Building: Institutional and Cultural Concordance", in Albright and Lovell, op.cit., pp.119-130.

47) Ibid., p.122.

48) Brown, op.cit., p.258.

49) Ibid., p.252. See also White, S., Gorbachev and after, Cambridge University Press, Cambridge 1992, p.187. 